Arch. histol. jap. Vol. 26, n. 5 (July 1966).

P. $535-546$.

Department of Anatomy (Prof. H. FUJITA), Hiroshima University School of Medicine, Kasumicho, Hiroshima, Japan.

\title{
Some Observations on the Fine Structure of the Development of the Pancreas in the Chick Embryo.
}

ニワトリ胎児膵臟の組織発生の微細構造についての二三の知見.

Yoshihiro TANIZAWA and Hisao FUJITA.

谷沢義弘と藤田尚男.

(Received May 26, 1966.)

Concerning the cell differentiation and the morphogenesis of the pancreas, electron microscopic studies have been published by several authors (MUNGER 1958a, b, PIPAN 1960, ZEIGEL 1962, KALLMAN and GROBSTEIN 1964). They mostly reported on the process of the first appearance of the secretory granule, especially on the ralationship between the cell organelles and the secretory substance. Though the authors agree with their observatiens on the whole, there are some remaining problems as to the morphogenesis of the gland.

The present paper concerns chiefly the differentiation of the centro-acinar cell and the occurrence of the physiological degeneration of the developing acinar cells in the embryonic stage.

\section{Materials and Methods.}

About 80 White Leghorn chick embryos ranging in age from 6 to 20 days of incubation were used in this study. The pancreas was fixed in $2.5 \%$ osmium tetroxide buffered with s-Collidine at $\mathrm{pH} 7.4$ for 2 hours. After dehydration with alcohol, the tissues were embəłded in an Epon epoxy resin (LUFT 1961). Sections cut with a PorterBlum ultramicrotome, were stained with lead acetate (MILLONIG 1963), and examined with a HITACHI Hs-6 type electron microscope. In addition, $1 \mu$ sections of the block were stained with toluidine-blue (YAMAMOTO 1963) for the light microscopic observation.

\section{Observations.}

Differentiation of the exocrine cells (Figs. 1-4).

The authors approximately agree with the description of ZEIGEL (1962) as to the differentiation of the acinar cell. The pancreas of 6-9 day-old embryos consists mainly of accumulates of immature glandular cells which are located at the terminal ends of the duct system (Fig. 1). The immature duct cells which surround the duct lumen are similar to immature glandular cells in their fine structure. The immature glandular cell is characterized by a rounded or oval nucleus, and scanty or relatively abundant cytoplasm with numerous polysomes and very few cytomembranes. 


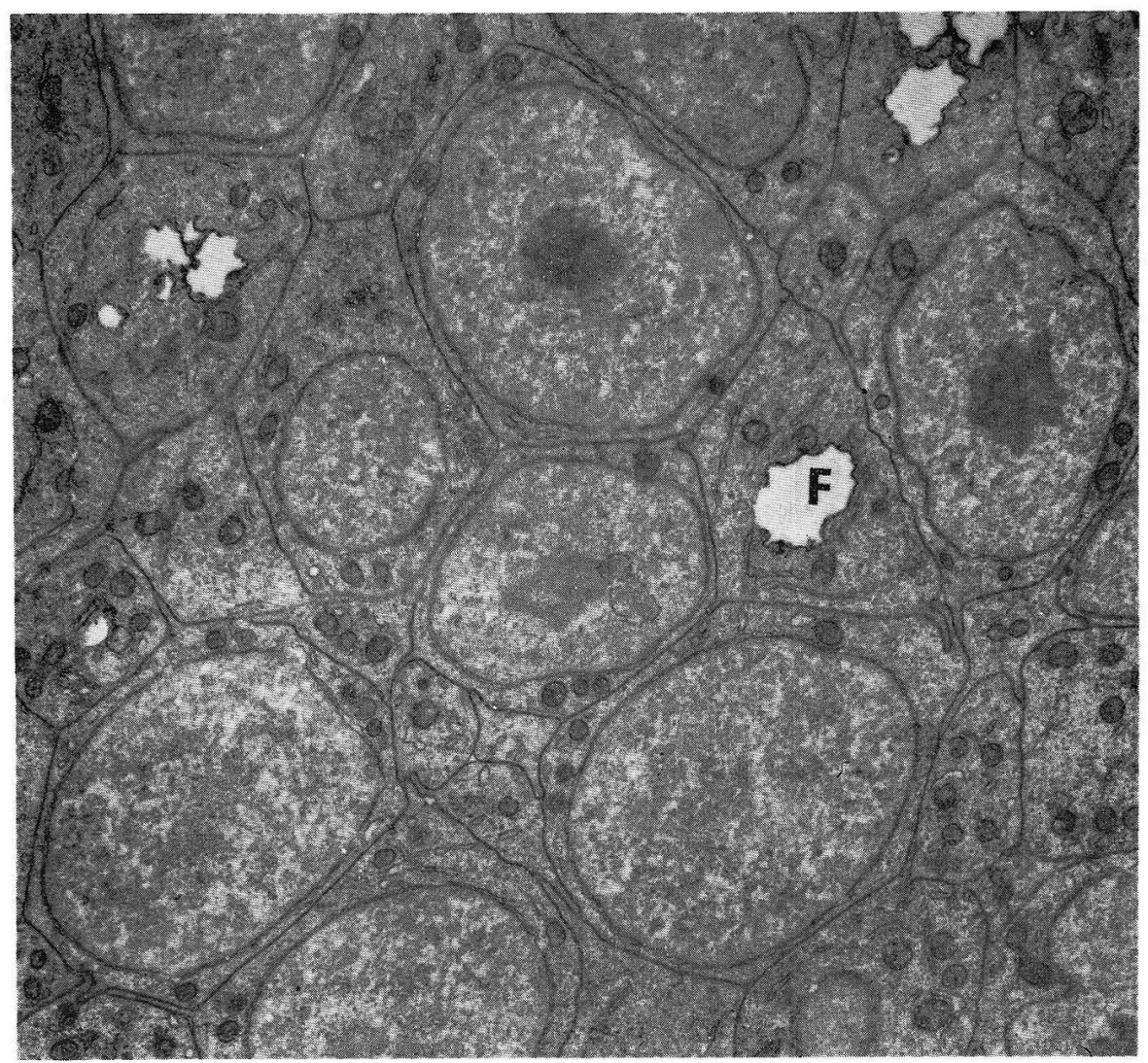

Fig. 1. Immature pancreatic cell masses of a 9 day-old chick embryo. $F$ fat droplet $\times 6,700$

Mitochondria with usual crests are scattered throughout the cytoplasm (Fig. 2). Relatively large $(1-3 \mu$ in diameter), irregularly shaped fat droplets are often noticed in the cytoplasm (Fig. 1). The immature duct cell, which has also numerous polysomes and few cytomembranes, is characterized by the occurrence of tonofilaments, interdigitations, microvilli, tight junctions and desmosomes. As ZEIGEL (1962) reported, one or two small $(0.1-0.3 / 6$ in diameter), rounded, homogeneously dense granules sug. gesting zymogen or prozymogen granules are present in rare cells (under $5 \%$ ) at 6 days. However, till 11 days, most cells are not functionally differentiated and are quite similar in appearance in electron micrograph to the immature gland cell described above. At 12 days, one third of pancreatic cells contain rounded, dense granules of $0.5-1.5 \mu$ diameter, which are similar to zymogen grauules of an adult animal in size, shape and electron density (Fig. 3). Though the cytoplasm has numerous free polysomes at $12-14$ days, the cytomembrane system including the roughsurfaced endoplasmic reticulum and Golgi apparatus is also relatively well developed as compared with that of the younger cell. The acinar cells having zymogen granules, and the secretory granules contained in each cell are increased in number in propor- 


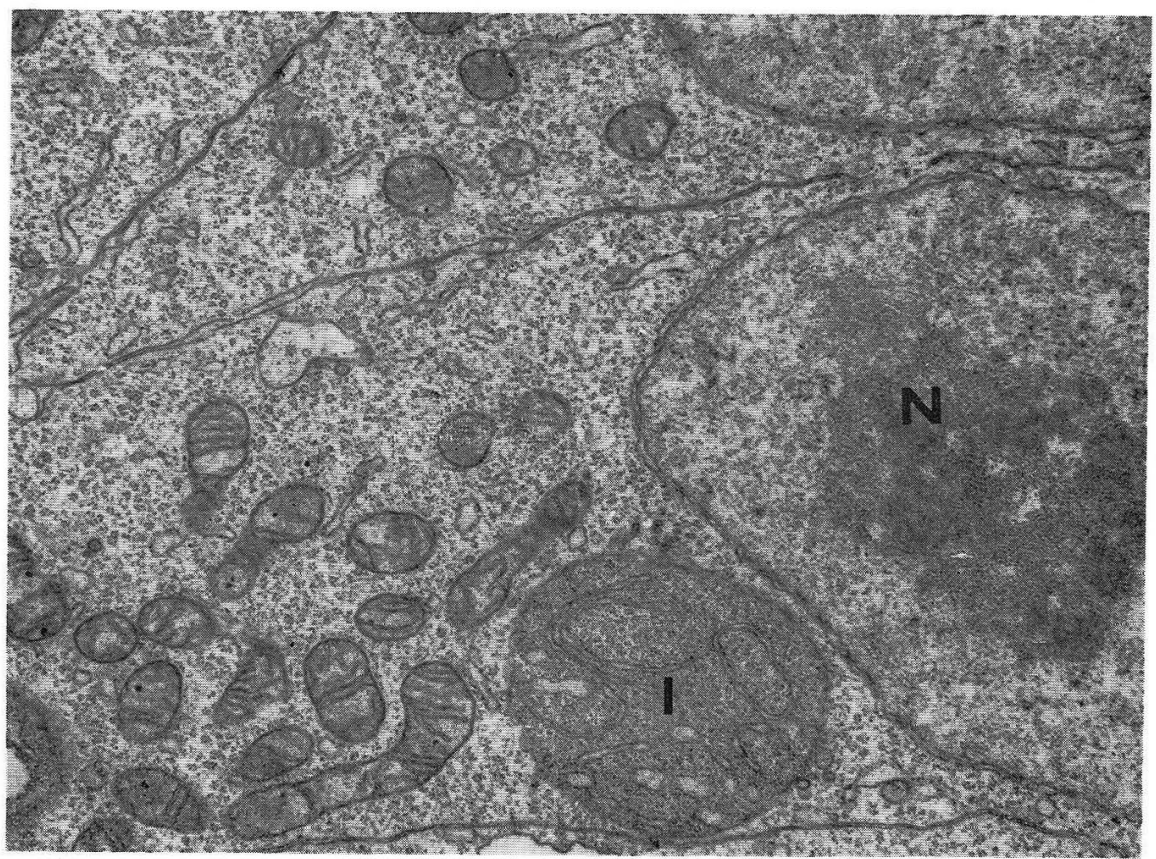

Fig. 2. Parts of threc immature pancreatic cells of a 6 day-old chick embryo. Notice abundant polysomes and few cytomembranes. $N$ nucleus, $I$ inclusion body suggesting the phagocytosed destructive material $\times 10,000$

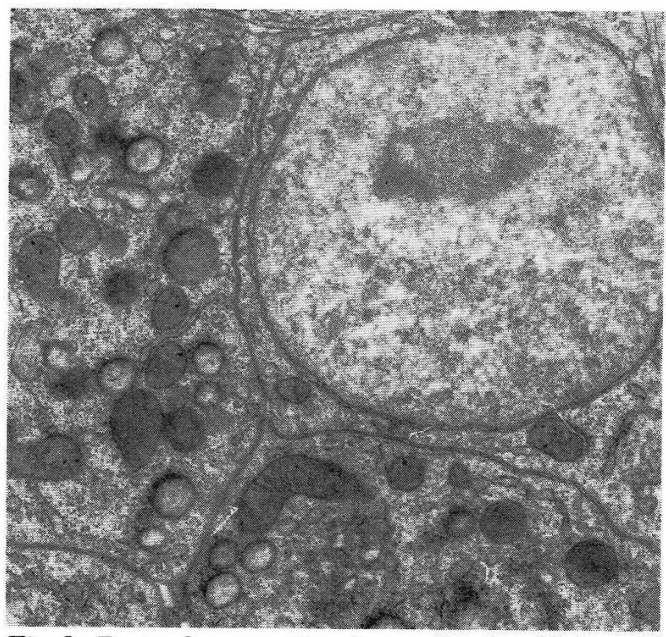

Fig. 3. Parts of pancreatic acinar cells of a 12 day old embryo. Notice homogeneously dark granules in the cytoprlasm. $\times 8,500$ tion to the development of the rough-surfaced endoplasmic reticulum. The small, irregularly shaped lumen, which is surrounded by two or more pancreatic cells, are noticed sporadically throughout the cell masses after 10 days. The free surface of the cell shows a small number of short microvilli of $0.1-0.2 \mu$ length projecting into the lumen. A typical junctional complex is seen at the edge of the lumen. These secretory lumina will be continuous with one another, and communicate with the duct system.

Endocrine cells with a fairly large number of round, highly

dense granules of $100-200 \mathrm{~m} \ell$ diameter appear sporadically at 6 days in the masses 


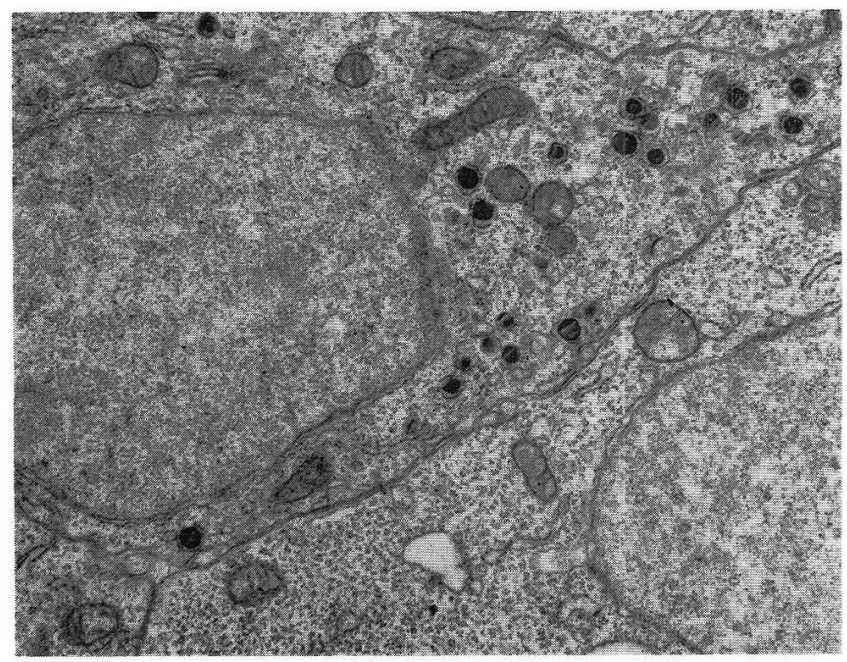

Fig. 4. An endocrine cell appearing in immature pancreatic cell masses of a 6 day-old embryo. Notice dark secretory granules suggesting the A-granules. $\times 8,500$

of the immature glandular cells (Fig. 4). From the shape, size, and density of this granule, the cell is considered to belong to an A-cell.

Differentiation of the centro-acinar cells (Figs. 5 and 6).

The rough-surfaced endoplasmic reticulum of the acinar cell becomes gradually developed with the lapse of days and makes an uncompleted lamellar structure in a 15 day-old embryo. On this day two kinds of cell are noticed in the exocrine part of the gland: (1) acinar cells with secretory granules, and (2) centro-acinar cells or centro ductular cells (HERMAN et al. 1964) characterized by the relatively light cytoplasm without secretory substance (Fig. 5, 6). The latter cells also sometimes participate in the formation of the wall of the secretory lumen. So the lumina appearing in the glandular tissue are classified into following three types: (1) those surrounded by only acinar cells, (2) surrounded by centro-acinar cells and acinar cells, and (3) surrounded by only centro-acinar cells. The type 3 corresponds to the intercalated duct. However, the intercalated duct seems not to be well developed in the embryonic stage, and it is not so easy to find out this kind of duct. In the developing centro-acinar cell, the nucleus is oval or rounded and the cytoplasm is characterized by its lightness and several short cytoplasmic processes stretching among acinar cells The endoplasmic reticulum is not so well developed and the mitochondria are few in number as compared with those of the acinar cell. The small Golgi apparatus consisting of small vesicles and lamellae is mostly located in the supranuclear region of the cell. Irregularly shaped, dense fat droplets are also sometimes found in this typo of cell. These structures are similar to those of the mature centro-acinar cells described by EKHOLM and EDLUND (1959) and EKHOLM et al. (1962). With the lapse of incubating days, the fine structural characteristics of the both cells become clearer. It is easy to distinguish the two at 17 days. 


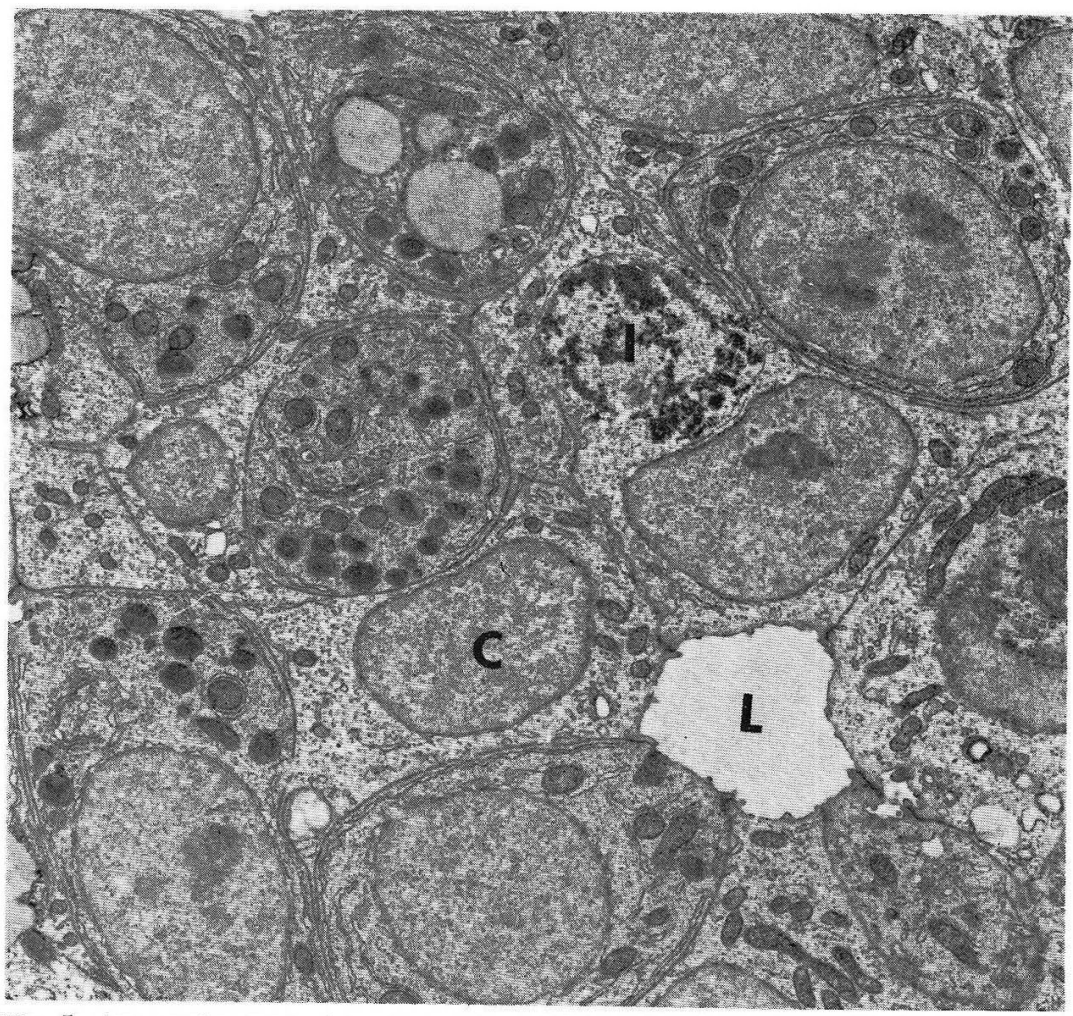

Fig. 5. An cxocrine part of a pancreas in a 17 day-old chick embryo. Notice the centroacinar cell $(C)$, inclusion body in the centro-acinar cell $(I)$, and a secretory lumen $(L)$. $\times 5,000$

Physiologic degeneration of the acinar cells (Figs. 7-9).

From about 6 to 17 days, a few cells suggesting the physiologic degeneration of acinar cells are noticed in the exocirne pancreas.

As described in the monograph of ROMANOFF (1960), the primitive lumina might be formed by the degeneration of the pancreatic cells. Among the immature cell masses, characteristic cells with markedly dark cytoplasmic matrix and swollen mitochondria are sporadically present (Fig. 7). This structure which is similar to the degenerating cell describad by BELLAIRS (1961) in the blastoderm of the chick embryo, might show the occurrence of a physiological degeneration of the immature glandular cells. A few of more differentiated acinar cells are also physiologically degenerated. In the 12-17 day especially 15-17 day-old embryos, a few degenerative cells are found. Enlarged cisternae of the rough-surfaced endoplasmic reticulum, and swollen mitochondria appear in these cells as first signs of the degeneration (Fig. 8, 9). Most of the destructive cells are in contact with the normal acinar cells as usual, and have zymogenic secretory granules in their cytoplasm. The endoplasmic reticulum in the normal acinar cell of the chick embryo from 13 to 20 days of incubation con- 


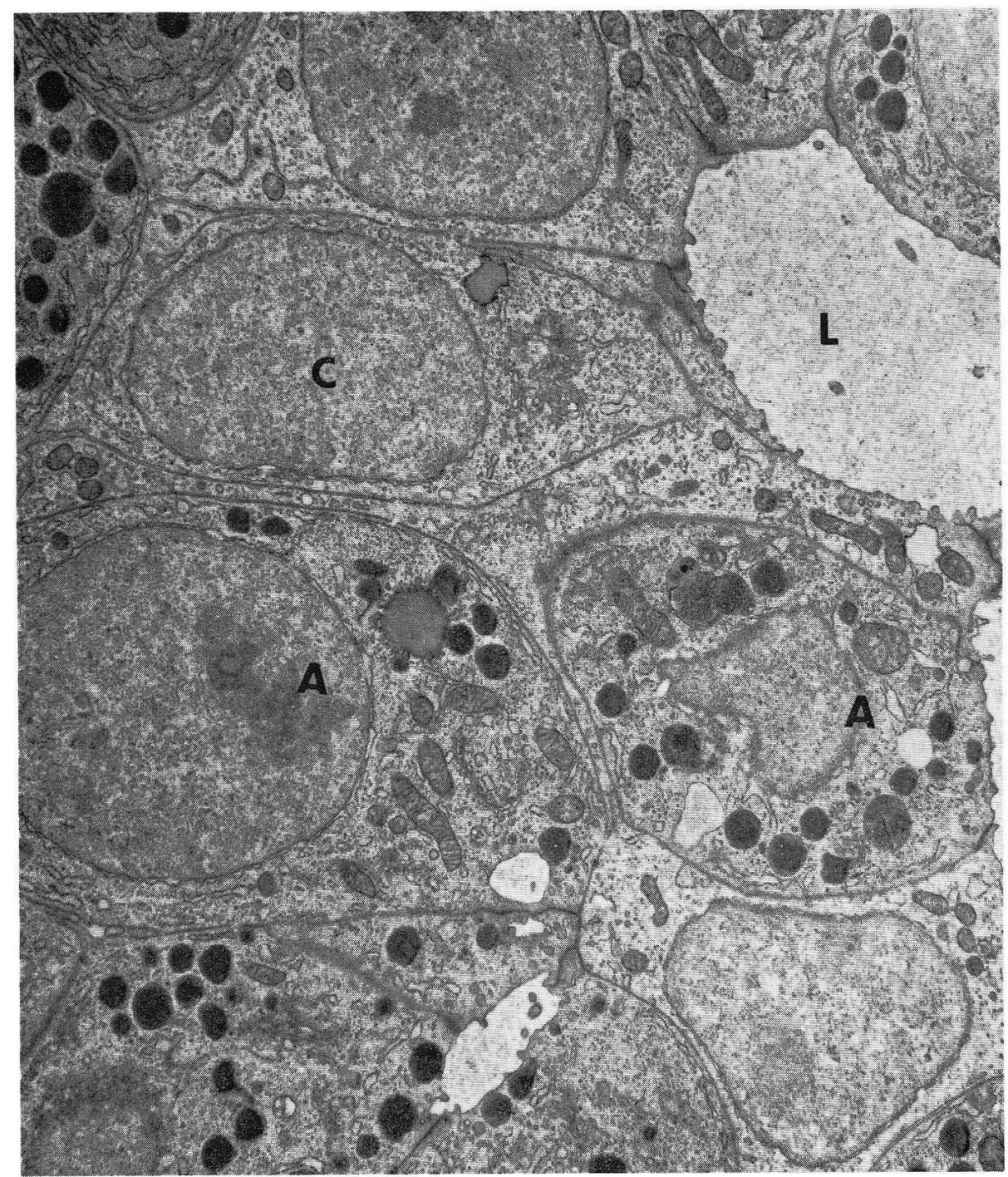

Fig. 6. An ex oxin cell, $L$ secretory lumen $\times 7,500$

sists of flattened sacs, and it is difficult to find a vacuolar cisterna. In the degenera. tive cells, most cisternae of the endoplasmic reticulum are vacuolarly enlarged, though the ribosomes on the outer surface of this structure are well reserved. The nuclear envelope is also enlarged and the rough-surfaced outer nuclear membrane projects into the cytoplasmic matrix in some parts. The mitochondrial swelling is also a striking change in the cytoplasm. Some swollen mitochondria become two or three times in length $(2-5 \mu)$ and over five times in width $(2-3 \mu)$ as compared with those of the 


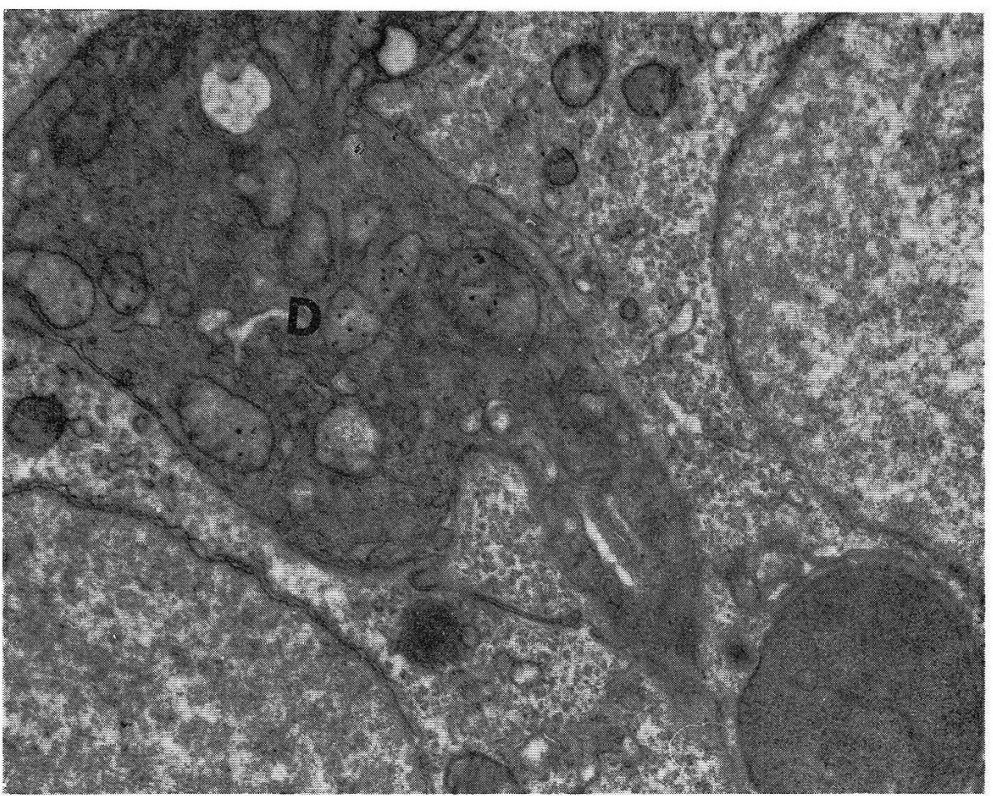

Fig. 7. A part of a dark cell $(D)$ suggesting the physiologic degeneration in a 6 dayold embryo pancreas. $\times 10,000$

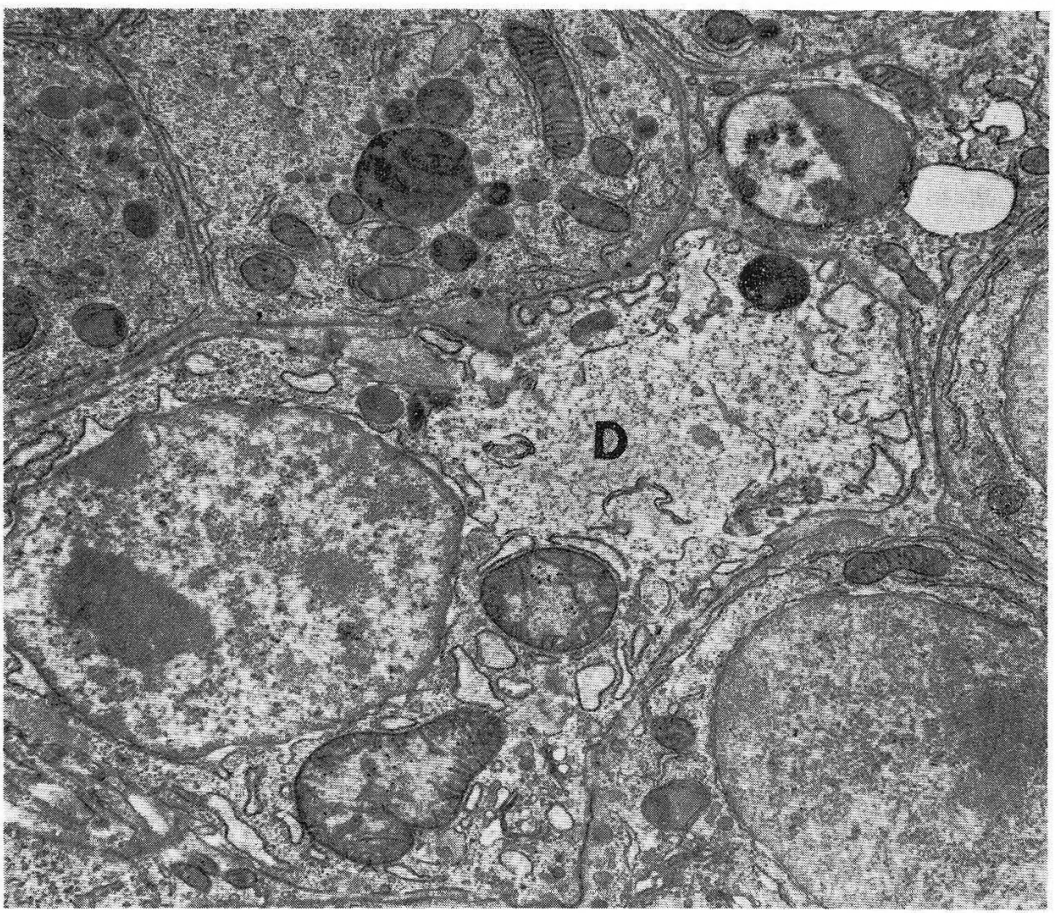

Fig. 8. A pancreatic cell suggesting the physiologic degeneration $(D)$ in a 17 day-old embryo pancreas. $\times 8,000$ 


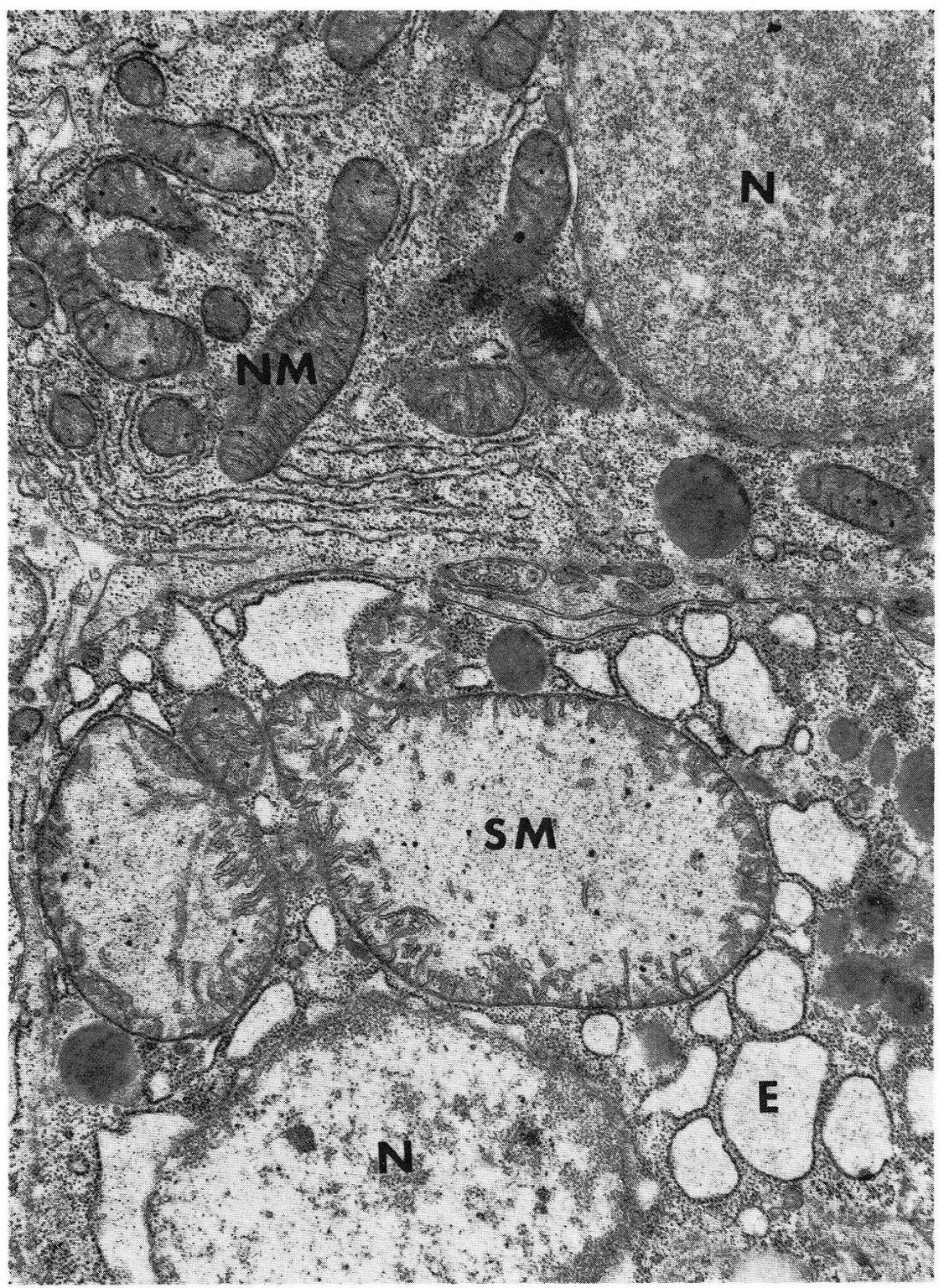

Fig. 9. A normal (upper) and a degenerative cell (lower) in a 17 day-old enbryo. Notice snall, elongated normal mitochondria $(N M)$ in the normal cell, and swollen mitochondria $(S M)$ and enlarged cisternae of rough-surfaced endoplasmic reticulum $(E)$ in the degenerative cell. $\times 18,000$

normal acinar cell. The crests are approximately the same in size as those of normal mitochondria, and a large less dense matrix without crests occupies the central portion of the mitochondrion. The cytoplasmic matrix of the degenerative cell becomes some- 
times dark and sometimes pale. The cell organelles are destroyed in some region of the cytoplasm, and the fragments of the cytomembrane are noticed there (Fig. 8). In the nuclear masses, the chromatin exhibits clumped density suggesting pyknosis. A few of centro-acinar cells contain a large, oval, heterogeneously dense inclusion body of $1-2 \mu$ diameter, enclosed by a limiting membrane in the cytoplasms, though it is not clear whether this is a phagocytotic material or not (Figs. 2 and 5).

\section{Discussion.}

Recently CARO and PALADE (1964) made it clear, using the electron microscopic autoradiography, that secretory proteins in the pancreatic acinar cells are synthesized in the rough-surfaced endoplasmic reciculum and are transported to the Golgi region to be matured into zymogen granules. In the pancreas of the chick embryo, the development of the rough-surfaced endoplasmic reticulum is closely related to the amount of zymogen granules in the acinar cell, as ZEIGEL (1962) pointed out. Though a few small dense granules rarely appear in the acinar cells of the 6 day-old chick embryo, most cells are fine structurally immature and characterized with numerous polyribosomes and few cytomembranes. The development of the rough-surfaced endoplasmic reticulum is reported by PORTER (1961), FUJITA and FUJITA (1963), and FUJITA and TANIZAWA (1966) as a sign of cell differentiation in nerve cells and thyroid cells. In most cells, this structure is strikingly well developed at 12 days in proportion to the increase of the zymogen granules. From this fact, most acinar cells are considered to be functionally differentiated at 12 days.

According to POTVIN and ARON (1927), the glandular tissue of the pancreas begins its differentiation on the eighth day ( $=7$ days), and according to VILLAMIL (1942) it is possible to identify cells of the exocrine acini and of the dark and light endocrine islands on this day. However, electron microscopically, a few endocrine cells are already differentiated at 6 days. From the size and density of the granules, these are considered to be A-cells. According to GIANNELI (1908) and VILLAMIL (1942), the differentiation of the islet cell is indicated by the appearance of an A-cell in the chick embryo, while, in the mouse pancreas, MUNGER (1958b) reported that the B.cell is differentiated at 13 days and the A.cell after birth. The secretory granules of the both types of islet cell are also produced in the Golgi region, as reported by numerous authors.

The centro-aoinar cell is a little distinguished fine-structurally from acinar cells at 15 days of incubation. The cell, relatively light in cytoplasmic density and without secretory granules, is clearly distinguished from the differentiated acinar cell containing well developed rough-surfaced endoplasmic reticulum and secretory granules in the cytoplasm. So it is difficult to detect the exact day when the centro-acinar cells are differentiated. It is a problem from which cells the centro-acinar cell is derived, from the immature duct cell or from the immature acinar cell. However, from the fact that the centro-acinar cells appear in the glandular cell masses, these cells are probably derived from the immature glandular cells.

As MUNGER (1958a) described that in all ages of the mouse embryo, certain cells demonstrate areas of cytoplasmic alterations suggesting degeneration, a few de- 
generative cells are found in 6-17 day-old chick embryo. Concerning the physiological death of the embryonal cells, GLÜCKSMANN (1951) published a detailed review. In this paper, he reported that the death of cells is related to the formation of lumina in solid or partly occluded organs, such as salivary glands; oesophageal glands and duodenum, but the pancreas was not described. According to POTVIN and ARON (1927), the physiologic degeneration is observed in the pancreatic islet of the chick embryo especially at 13 to 15 days of incubation. BELLAIRS (1961), and DEAN and WURZELMANN (1965), using the electron microscope, treated in detail of the cell death in the blastoderm of the chick embryo and on the occurrence of a degenerative cell in the postnatal process of the seminal vesicle epithelium. The degeneration product could be phagocytosed by the surrounding cells according to GLÜCKSMANN (1951), BELLAIRS (1961), and DEANand WURZELMANN (1965).

A characteristic heterogeneously dense inclusion body, which is contained in the immature glandular or centro-acinar cell, and similar to the phagocytosed material shown as such by BELLAIRS (1961) and DEAN and WURZELMANN (1965), might be a phagocytosed substance (Fig. 2, 5). The degeneration of some pancreatic exocrine cells in the embryonic stage is considered to be a physiological phenomenon necessary for the cell arrangement of the gland.

\section{Summary.}

Normal pancreas of White-Leghorn chick embryo, ranging in age from 6 to 20 days of incubation, was observed with the electron microscope.

1) The pancreas of 6-9 day-old embryos consists mainly of accumulates of immature glandular cells which are located at the terminal portions of the duct system. The immature glandular cell is characterized by numerous polysomes and few cytomembranes. A small number of round, dense granules presumably of the zymogen or prozymogen substances appear in rare cells at 6 days.

2) The acinar cells containing zymogen granules, and the granules contained in each cell are increased markedly in number at 12 days. The development of the roughsurfaced endoplasmic reticulum is closely related to this increase in the amount of the zymogen granules in the cell.

3) Endocrine cells, presumably A-cells, appear sporadically among the immature cell masses at 6 days of incubation.

4) The centro acinar cell begins to be noticed in the exocrine part of the gland at 15 days. This cell is characterized by a light cytoplasm without secretory granules. It becomes easy to distinguish the acinar cell and the centro-acinar cell at 17 days.

5) The occurrence of the physiologic degeneration of a few immature or a few differentiated acinar cells in the embryonic stage is reported and discussed.

\section{内 容 自 抄.}

孵卵 6 日より20日までの白色レグホン種ニワトリ胎児の膵臓を電子顕微鏡で観 察し, 次の所見を得た。

瑷卵6〜9日の萃藏は，おむに導管系につづいている未分化の腺細胞の塊からな 
る。

未分化腺細胞は細胞質内にあまねく存在する多数の polysomes と, cytomembrane の発達が極めて悪いことによって特徵づけられる。

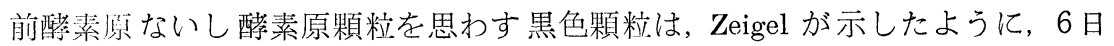
頃に極めて少数の細胞内にごく少数出現する。しかし11日頃までは顆粒形成はほ とんど進まない，12日頃に，粗面小胞体の発達と平行して，䤏素原顆粒と関係深 い上思われる顆粒が約 $1 / 3$ の細胞にかなり多数出現してくる.

一方 $\mathrm{A}$ 䊼胞之思われる内分泌細胞は，未分化腺細胞塊の中に散在性に 6 日にす でに出現している。

腺房中心細胞は外分泌細胞塊の中に出現するが，それらの細胞は15日頃によう やく区別せられ，17日には一層明蹽になる．少数の未分化腺細胞および分化した 外分泌細胞が生理的変性を起こす所見を得たが，乙れは細胞の配列に必要な変化 亡思わ机る。

\section{References.}

Bellairs, R. : Cell death in chick embryos as studied by electron microscopy. J. Anat. 95 (1961). P. 54-60. - Caro, L. G. and G. E. Palade: Protein synthesis, storage, and discharge in the pancreactic exocrine cell. J. Cell Biol. 20 (1964). P. 473-495. - Dean, H. W. and S. Wurzelmann: Electron microscopic obsarvations on the postnatal differentiation of the seminal vesicle epithelium of the laboratory mouse. Am. J. Anat. 117 (1965). P. 91-134. — Ekholm, R. aud Y. Edlund: Ultrastructure of the human exccrine pancreas. J. Ultrastr. Res. 2 (1959). P. 453-481. - Ekholm, R., T. Zelander and Y. Edlund: The ultrastructural organization of the rat exocrine pancreas. II. Centroacinar cells, intercalary and intralobular ducts. J. Ultrastr. Res. 7 (1962). P. 73-83. - Fujita, H. and S. Fujita: Electron microscopic studies on neuroblast differentiation in the central nervous system of domestic fowl. Z. Zellforsch. 60 (1963). P. 463-478. - Fujita, H. and Y. Tanizawa : Electron microscopic studies on the development of the thyroid gland of chick enbryo. Z. Anat. Entw.-Gesch. in the press (1966). - Gianneli, L.: Morit. zool. ital. 19 (1908). P. 198-199. (from Romanoff). - Guücksmann, A.: Cell deaths in normal vertebrate ontogeny. Biol. Rev. 26 (1951). P. 101-110. - Herman, L, T. Sato and P. J. Fitzgerald: In: (єd. by). S. M. Kurtz: Electron microscopic anatomy. P. 60-74, 1964. Academic Press, New York and London. - Luft. J. H.: Improvement in epoxy resin embedding methods. J. biophys. biochem. Cytol. 9 (1961). P. 408-414. — Millonig, G.: A modified procedure for lead staining of this sections. J. biophys. biochem. Cytol. 11 (1961). P. 736739. - Munger, B. L. : A phase and electron microscopic study of cellular differentiation in pancreatic acinar cells of the mouse. Am. J. Anat. 103 (1958a). P. 1-34. - A light and electron microscopic study of cellular differentiation in the pancreatic islet of the mouse. Am. J. Anat. 103 (1958b). P. 275-312. - Pipan, N.: Licht und electronenmikroskopische Uutersuchungen über die Differenzierung des embrycnalen Pancreas der Maus. Z. Zellforsch. 52 (1960). S. 291314. - Porter, K. R.: The ground substance, observations from electron microscopy. In: Brachet and Mirsky: The Cell. II. 1961. Academic Press, New York. - Potvin, R. and M. Aron: C. r. Soc. Biol. Paris 96 (1927). P. 267-269. (from Romanoff). - Romanoff, A. L. : The Avian Embryo. 1960. Macmillan Company, New York. - Villamil, M. F.: Cytogenesis del pancreas exo-y-endocrịne chez l'embryon de pollo. Rev. Șoc. Arg. Biol. 18 (1942). P. 426- 
428. (from Romanoff). - Yamamoto, T.: A method of toluidine blue stain for epoxy embedded tissues for light microscopy. Acta anat. nippon. 48 (1963). P. 124-128. - Zeigel, R. F.: Cytogenic study of exbryonic chick pancreas. I. exorrine tissue. J. National Cancer Inst. 28 (1962). P. 269-303. 